\title{
EEF1B2 Gene
}

National Cancer Institute

\section{Source}

National Cancer Institute. EEF1B2 Gene. NCI Thesaurus. Code C38961.

This gene is involved in protein synthesis. 